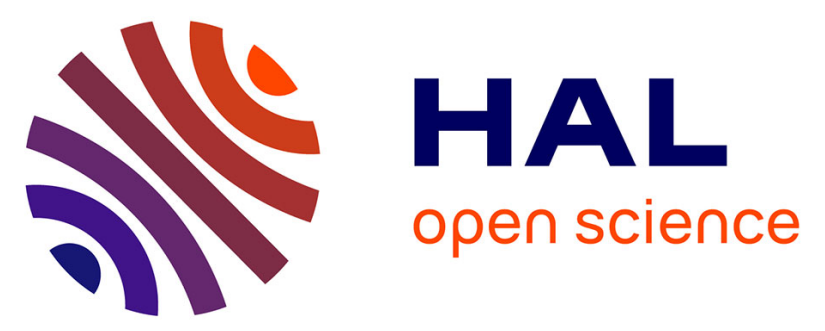

\title{
Lipase-catalysed polycondensation of levulinic acid derived diol-diamide monomers: access to new poly(ester-co-amide)s
}

Julie Meimoun, Yann Bernhard, Lydie Pelinski, Till Bousquet, Sylvain Pellegrini, Jean-Marie Raquez, Julien de Winter, Pascal Gerbaux, Frédéric Cazaux, Jean-François Tahon, et al.

\section{To cite this version:}

Julie Meimoun, Yann Bernhard, Lydie Pelinski, Till Bousquet, Sylvain Pellegrini, et al.. Lipasecatalysed polycondensation of levulinic acid derived diol-diamide monomers: access to new poly(esterco-amide)s. Polymer Chemistry, 2020, 11 (47), pp.7506 - 7514. 10.1039/d0py01301c . hal-03263321

\section{HAL Id: hal-03263321 \\ https://hal.science/hal-03263321}

Submitted on 30 Jun 2021

HAL is a multi-disciplinary open access archive for the deposit and dissemination of scientific research documents, whether they are published or not. The documents may come from teaching and research institutions in France or abroad, or from public or private research centers.
L'archive ouverte pluridisciplinaire HAL, est destinée au dépôt et à la diffusion de documents scientifiques de niveau recherche, publiés ou non, émanant des établissements d'enseignement et de recherche français ou étrangers, des laboratoires publics ou privés. 
Lipase-catalysed polycondensation of levulinic acid derived diol-diamide monomers: access to new poly(ester-co-amide)s

Julie Meimoun, ${ }^{a}$ Yann Bernhard, ${ }^{a}$ Lydie Pelinski, ${ }^{a}$ Till Bousquet, ${ }^{a}$ Sylvain Pellegrini, ${ }^{a}$ Jean-Marie Raquez, ${ }^{b}$ Julien De Winter, ${ }^{c}$ Pascal Gerbaux, ${ }^{c}$ Frédéric Cazaux, ${ }^{d}$ Jean-François Tahon, ${ }^{d}$ Valérie Gaucher, ${ }^{d}$ Thomas Chenal, ${ }^{a}$ Audrey Favrelle-Huret, ${ }^{a}$ Philippe Zinck $^{* a}$

a Univ. Lille, CNRS, Centrale Lille, Univ. Artois, UMR 8181 - UCCS - Unité de Catalyse et Chimie du Solide, F-59650 Villeneuve d'Ascq, France.

b Univ. Mons - UMONS, Matériaux Polymères \& Composites, 23 Place du Parc, B-7000 Mons, Belgium

${ }^{\mathrm{C}}$ Univ. Mons - UMONS, Organic Synthesis \& Mass Spectrometry Laboratory, 23 Place du

Parc, B-7000 Mons, Belgium

d Univ. Lille, CNRS, INRAE, Centrale Lille, UMR 8207 - UMET - Unité Matériaux et

Transformations, F-59000 Lille, France

*philippe.zinck@univ-lille.fr

Research toward bio-based polymers is an expanding field due to environmental concerns. A library of new aliphatic diol-diamide monomers with different chain lengths between the two amido groups was synthesized from sustainable levulinic acid and various linear aliphatic diamines $\left(C_{2}-C_{10}\right)$. The monomers were prepared by diacylation of the diamines followed by reduction of the ketones to alcohols. These secondary diols were successfully recognized by the enzyme and polymerised in solution through a lipase-catalysed polycondensation. Poly(ester-co-amide)s with number-average molecular weights $\left(M_{n}\right)$ in the range 1,300 - 7,200 $\mathrm{g} / \mathrm{mol}$ were obtained, with dispersities between 1.5 and 1.8. An improvement of the $M_{\mathrm{n}}$ was observed increasing the monomer chain length. The variation of the aliphatic diol allows modulating the thermal properties of final polymers. The glass transition temperatures were found between $-23^{\circ} \mathrm{C}$ and $0{ }^{\circ} \mathrm{C}$. The polymers, containing long aliphatic segment $\left(\mathrm{C}_{8}-\mathrm{C}_{10}\right)$, were able to crystallize (melting temperature of $90-97{ }^{\circ} \mathrm{C}$ ). TGA analyses showed that the ester linkages degrade at lower temperatures than the amide bonds. The stability of the latter was found to be higher when the number of methylene units increased from $2\left(355^{\circ} \mathrm{C}\right)$ to $10(378$ $\left.{ }^{\circ} \mathrm{C}\right)$. This kind of biopolymers could be served as drug delivery systems or for tissue engineering applications.

Introduction

Research toward bio-based polymers is a growing and important field due to environmental concerns and fossil resources depletion. This encourages the transformation of the renewable biomass, i.e. starch, oil and lignocelluloses into valuable chemical molecules, especially monomers. ${ }^{1,2}$ Alternatively, the polysaccharide feedstock gives access to different green chemical building blocks such as 5-HydroxyMethylFurfural (HMF), lactic, succinic, glutaric and levulinic acids. ${ }^{3,4}$ As being recognized as one of the top 12 building blocks, levulinic acid is a promising bio-based platform due to its competitive cost and large scale production (around 2,600 tons per year) from renewable feedstocks. Generally, mineral acid (sulfonic, hydrochloric and methanesulfonic acids) catalysed treatment of sugars (glucose, fructose, 
galactose, xylose), obtained from the hydrolysis of polysaccharides such as cellulose, lignocellulose, hemicellulose or starch, gives access to HMF or furfural (transform in furfuryl alcohol by reduction), which upon rehydratation leads to levulinic acid (Scheme 1)..$^{5-7}$ This process yields 34 to $80 \%$ levulinic acid depending on precursors. ${ }^{8}$ Formic acid is formed as a by-product reaction which can be used as commodity chemical in the production of formaldehyde, rubber and plasticizers. ${ }^{9}$ The use of heterogeneous catalysts, such as Amberlite IR 120, clay minerals, zeolites, was reported as an alternative to mineral acid, due notably to the difficulty to recover the former, with yields up to $70 \% .^{8}$

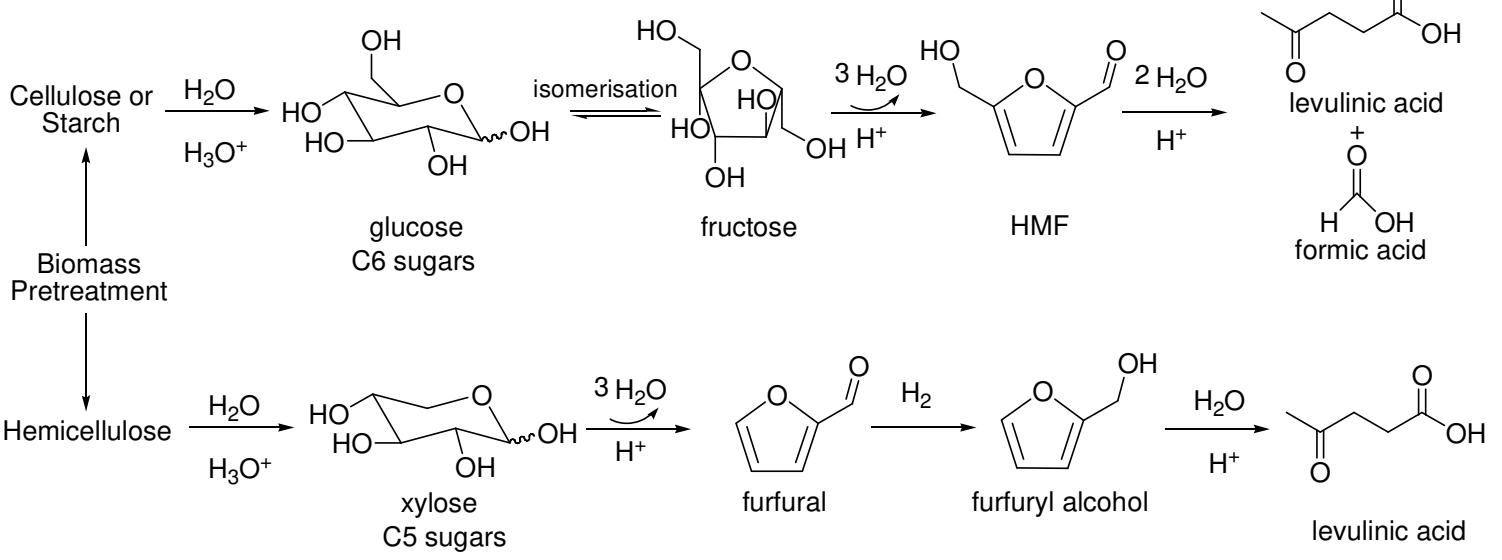

Scheme 1 Different pathway to access to levulinic acid from biomass. ${ }^{5,7,8}$

Levulinic acid can be converted into value-added products finding application in several fields such as fuel, additives, pharmaceutical intermediates, solvents, plasticizers and polymers. ${ }^{8,10-12}$ For example, a library of biobased ketal-diester derivatives of levulinic acid plasticizers was synthesized and improved the properties of poly(vinyl chloride) material. ${ }^{13}$ The conversion of levulinic acid into valuable monomers is also an interesting way to obtain renewable specialty polymers. For instance, poly(amine-co-ester)s, ${ }^{14}$ and polyesters bearing a pendant lactam group, ${ }^{15,16}$ were recently prepared from levulinic acid via reductive amination or via a multicomponent reaction. The condensation of levulinic acid with glycerol and erythritol to form ketals has also been exploited to access to polyesters and polyurethanes. ${ }^{17-}$ 19 Levulinic acid can also be directly converted into $\gamma$-valerolactone, which can be directly polymerised or further transformed into diol-diamide valuable precursors for polyurethane $\mathrm{e}^{20-}$ 22 and poly(ester-co-amide) ${ }^{23}$ syntheses.

Bio-based poly(ester-co-amide)s have been less investigated than bio-based polyesters or polyamides. ${ }^{24-27}$ Poly(ester-co-amide)s are biodegradable polymers with great potential in the biomedical field notably. They have been incorporated in controlled drug delivery systems, ${ }^{28}$ hydrogels, ${ }^{29}$ tissue engineering ${ }^{30}$ and adhesives. ${ }^{31}$ The presence of ester and amide moieties in their structure confers to them the degradable character of the ester linkage and good thermal and mechanical properties due to the hvdrogen-bonding abilities of the amide groups. The incorporation of amides bond into the backbone of polvesters (polvethylene succinate, polvpropylene succinate, polvbutylene succinate...) was reported via copolvmerisation of crvstallizable svmmetrical diols containing two internal amide bond (from for example the reaction of $\varepsilon$-caprolactone $/ \gamma$-butyrolacrone and different diamine), diol (eq. ethvlene glvcol, 1,3-propanediol, 1,4-butanediol) and diacid/diester. The purpose was to enhance the thermal properties of polyesters via introduction of amide groups. ${ }^{32,33,34}$ The mechanical properties 
were also improved, with higher elastic modulus and stress at break. ${ }^{35}$ The properties can be tuned by changing the ratio of the comonomers.

Different routes have been explored for the synthesis of poly(ester-co-amide)s. ${ }^{36,37}$ The ring-opening polymerisation (ROP) of cyclic depsipeptides, mediated via either stannous octoate $^{38}$ or an enzyme, ${ }^{39}$ has been described. The ring-opening polymerisation of $\mathrm{N}$-acylated1,4-oxazepan-7-one monomers catalysed by the 1,5,7-triazabicyclo[4.4.0]dec-5-ene (TBD)/thiourea combination was also described to access to poly(ester-co-amide)s via controlled/living polymerisation. ${ }^{40}$ Base-catalysed step-growth reactions involving activated acyl chloride/dicarboxylic acid derivatives by incorporation of leaving group agent (e.g.: acyl chloride or $p$-nitrophenol, $p$-chlorophenol- $N$-hydroxysuccinimide esters) ${ }^{41,42}$ or interfacial polycondensation ${ }^{43}$ were reported as well as metal-catalysed melt polycondensation. ${ }^{43}$

Enzyme-catalysed polycondensation has also been reported as an efficient and eco-friendly strategy to prepare poly(ester-co-amide)s. ${ }^{44}$ For example, an amide-amino-alcohol monomer bearing a primary alcohol was polymerised with diethyl sebacate in diphenyl ether under vacuum. ${ }^{45}$ Furan-aliphatic poly(ester-co-amide)s were also synthesized from primary diol, diamine (or amino-alcohols) and dimethyl 2,5-furandicarboxylate by enzymatic polycondensation in toluene or in ionic liquid solvent. ${ }^{46}$ The synthesis of poly(ester-co-amide)s with polydimethylsiloxane blocks was also successfully performed in bulk via lipase catalysis under mild conditions using the association of three monomers : diethyl adipate. 1.8octanediol, and $\alpha, \omega$-(diaminopropvl)polvdimethvlsiloxane. ${ }^{47}$ As a matter of fact, enzvmatic polvcondensation was significantlv less reported for the svnthesis of polv(ester-co-amide) $s^{44}$ compared to the impressive amount of research devoted to polyesters ${ }^{48-52}$ and polyamides. ${ }^{45,53-55}$ Among the lipases, Novozyme 435 (immobilized Candida antarctica lipase B), is probably the most widely applied. However, due to the low reactivity of lipases towards secondary alcohols, most of the polycondensations were conducted from primary alcohols. It was shown for instance that the enzymatic polyesterification of sorbitol or glycerol with adipic acid leads to polyesters with unreacted pendant secondary hydroxyl groups (respectively $95 \%$ and $66 \%) .{ }^{56}$ The enzymatic polycondensation of sebacic acid with aliphatic diols containing both primary and secondary alcohol groups was also reported with number average molecular weight $\left(M_{\mathrm{n}}\right)$ up to $5,700 \mathrm{~g} / \mathrm{mol}^{57}$ In addition to steric hindrance, the presence of an asymmetric center has proven to have an impact on the reactivity of lipase toward secondary diols as well. As an illustration of this, it has been highlighted that the enantioselectivity of the lipase towards the $R$-configured centers of the racemic $\alpha, \alpha^{\prime}$-dimethyl-1,4-benzenedimethanol leads to reduce the total conversion (reactivity ratio $\mathrm{R} / \mathrm{S}=10^{6}$ ). ${ }^{58} \mathrm{It}$ is finally worth mentioning that the synthesis of polyesters from a bicyclic secondary diol, isosorbide (1,4:3,6-dianhydroD-sorbitol), with molecular weights up to $M_{\mathrm{n}}=20,000 \mathrm{~g} / \mathrm{mol}$ has been reported in the literature. ${ }^{59}$

Due to the poor recognition of secondary alcohols by lipases, it is challenging to get a polymer from secondary diol by enzymatic polycondensation. As discussed previously, only few studies presented the synthesis of poly(ester-co-amide)s via enzymatic catalysis, ${ }^{45-47}$ and to our knowledge, we report herein the first example of a step-growth synthesis of poly(esterco-amide) polymers from a secondary diol via biocatalysis. The synthesis of new secondary diol-diamide monomers from the renewable levulinic acid and diamines was reported. These diols were successfully polymerised with diethyl adipate via enzymatic polycondensation, giving access to a library of new bio-based biodegradable poly(ester-co-amide)s which could be serve in the medical field.

\section{Experimental}

\section{Materials}

Levulinic acid (98\%), 1,4-diaminobutane (98\%), 1,5-diaminopentane (98\%), 1,10diaminodecane (98\%) were supplied by Alfa Aesar. Triethylamine (99\%), ethyl chloroformate (99\%), 1,2-diaminoethane (99\%), 1,3-diaminopropane (99\%), 1,8-diaminooctane (98\%) were provided by Acros. Sodium borohydride (99\%), 1,6-diaminohexane (98\%), adipic acid (99\%), sebacic acid (99\%), diethyl adipate (99\%) were supplied by Aldrich. Diethyl sebacate (98\%) was 
supplied by $\mathrm{TCl}$ Europe. Novozyme 435 was kindly provided bv Novozvmes A/S. All the reactants and solvents (from VWR) were used as received. The synthesized monomers were obtained with high puritv after purification (silica gel column chromatography and then recrystallization) as assessed by the NMR analysis (Supporting Information section). Analytical thin layer chromatography (TLC) was performed on commercial silica gel $60 \AA$ with fluorescent indicator UV absorbance $254 \mathrm{~nm}$ (Merck). Detection was accomplished by treatment of the plate with dying reagents (potassium permanganate, vanillin or anisaldehyde). Chromatographic purifications of compounds $2 \mathrm{a}-\mathrm{g}$ were performed on silica gel columns (silica $60 \AA, 40-63 \mu \mathrm{m})$.

\section{General procedure for diketones-diamides (1a-g) syntheses (Scheme 2)}

In a $1 \mathrm{~L}$ round bottom flask, levulinic acid $(10 \mathrm{~g}, 86.1 \mathrm{mmol})$ was dissolved in diethyl ether $(300 \mathrm{~mL})$. The mixture was ice cooled and triethylamine $(12 \mathrm{~mL}, 86.1 \mathrm{mmol})$ was added. After stirring $5 \mathrm{~min}$ at room temperature, ethyl chloroformate $(8.2 \mathrm{~mL}, 86.1 \mathrm{mmol})$ was quickly added, resulting in the formation of a white solid. After $15 \mathrm{~min}$ additional stirring, the precipitate was filtered off and washed once with diethyl ether $(200 \mathrm{~mL})$. The filtrate was transferred into a $1 \mathrm{~L}$ round bottom flask and vigorously stirred in an ice bath. The chosen diamine ( $43.1 \mathrm{mmol}, 0.5 \mathrm{eq}$ ) was added at once and the heterogeneous mixture was stirred for $1-2 \mathrm{~h}$ at room temperature. The operating procedure slightly differed for the ethylene diamine (product 1a) and the propane diamine (product $1 \mathrm{~b}$ ). In those cases, the diamine was dissolved in $50 \mathrm{~mL}$ of dichloromethane (DCM) and was added dropwise to the reaction mixture via a dropping funnel over $30 \mathrm{~min}$. In all cases, the white precipitate was filtered off and washed twice with diethyl ether $(2 \times 100 \mathrm{~mL})$, then dried under vacuum for several hours, yielding the pure desired products $1 \mathrm{a}-\mathrm{g}$.

\section{General procedure for diols-diamides (2a-g) syntheses (Scheme 2)}

Compound 1a-g (32 mmol) was suspended in methanol $(200 \mathrm{~mL})$ and the mixture was ice cooled. Then sodium borohydride $(3.63 \mathrm{~g}, 96 \mathrm{mmol}$ ) was added by portion in the mixture over a period of $10 \mathrm{~min}$. After complete addition, the reaction was stirred at room temperature for 2-5 $\mathrm{h}$ and monitored by $\mathrm{TLC}\left(\mathrm{SiO}_{2}\right.$ plates, $\mathrm{DCM} / \mathrm{MeOH} 95 / 5, \mathrm{KMnO}_{4}$ stain). As soon as the starting material was totally consumed, the reaction mixture was concentrated under vacuum. The resulting residue was purified by silica gel column chromatography $(\mathrm{DCM} / \mathrm{MeOH}$, from $95 / 5$ to $85 / 15$ ), yielding the product as a white solid. A further recrystallization can be performed from tetrahydrofuran to ensure an optimal purity.

\section{General procedure for polymer syntheses}

The experimental procedure is adapted from a study on enzyme-catalysed polycondensation of a secondary diol..$^{59}$ Diol $2 \mathrm{a}-\mathrm{g}(0.5 \mathrm{mmol})$, a diacid or a diester $(2 \mathrm{mmol})$ and Novozyme 435 (10 wt\%) were charged in a 50 or $100 \mathrm{~mL}$ round bottom flask containing $20-60 \mathrm{~mL}$ of cyclohexane. A Dean Stark apparatus was connected to the round bottom flask. In the case of reactions with diester, the Dean Stark apparatus was filled with molecular sieves (4 A) to ensure trapping ethanol (cyclohexane: $d=0.779$, ethanol: $d=0.789$ ). The molecular sieves were replaced every 48 hours. It is worth noting that it was not necessary to use molecular sieves in the case of diacids (cyclohexane: $d=0.779$, water: $d=0.999$ ). The reaction was carried out under reflux for 7 days. At the end of the reaction, the final mixture containing the insoluble product was dissolved into an excess of chloroform and then filtered off to remove the supported enzyme and eventual residues of diol or diacid. The solvent was evaporated, and the product was dried under vacuum for 24 hours.

\section{Analytical methods}

${ }^{1} \mathrm{H}$ NMR and ${ }^{13} \mathrm{C}$ NMR spectra were recorded on a Bruker $\mathrm{AC} 300$ spectrometer at room temperature in DMSO- $\mathrm{d}_{6}(0.5 \mathrm{~mL}$, number of scans $=16$, delay of relaxation $=3)$. If necessary, to improve the solubility of the polymer, $0.1 \mathrm{~mL}$ of $\mathrm{CDCl}_{3}$ was added in the NMR tube. Chemical 
shifts were reported in ppm relative to the residual solvent peak. Multiplicities were given as $\mathrm{s}$ (singlet), $\mathrm{d}$ (doublet), $\mathrm{t}$ (triplet) and $\mathrm{m}$ (multiplet). Coupling constants $\mathrm{J}$, were reported in $\mathrm{Hz}$. If required, chemical shifts were fully attributed using a COSY experiment. High resolution mass spectra (HRMS) were measured on a Waters Synapt G2- Si (mode ESI(+) with Leucine Enkephalin ions - $m / z 556.2771$ - as the lock mass). The samples were first dissolved in Acetonitrile/Methanol 1/1 (HPLC grade) at a concentration of $0.1 \mathrm{mg} / \mathrm{ml}$ and the solutions were directly infused $(5 \mu \mathrm{l} / \mathrm{min})$ in the ESI source (capillary voltage: $3.1 \mathrm{kV})$. Positive-ion Matrix assisted LASER Desorption/Ionization-Mass Spectrometry (MALDI-MS) experiments were performed using a Waters QToF Premier mass spectrometer equipped with a Nd:YAG laser operating at $355 \mathrm{~nm}$ (third harmonic) with a maximum output of $65 \mu \mathrm{J}$ delivered to the sample in $2.2 \mathrm{~ns}$ pulses at $50 \mathrm{~Hz}$ repeating rate. Time-of-flight mass analysis was performed in the reflectron mode at a resolution of about $10 \mathrm{k}(\mathrm{m} / \mathrm{z} 569)$. All samples were analysed using trans2-[3-(4-tert-butylphenyl)-2-methylprop-2-enylidene]malononitrile (DCTB) as a matrix. Polymer samples were dissolved in mixture of chloroform/THF $(50 / 50)$ to obtain $1 \mathrm{mg}^{\mathrm{mL}} \mathrm{m}^{-1}$ solution. Additionally, $40 \mu \mathrm{L}$ of $2 \mathrm{mg}^{\mathrm{mL}} \mathrm{mL}^{-1} \mathrm{Nal}$ solution in acetonitrile was added to the polymer solution. The number-average molecular weight $\left(M_{n}\right)$ and the molar mass dispersity $\left(\theta_{M}\right)$ were determined by Size Exclusion Chromatography (SEC). The apparatus (Agilent Technologies) is equipped with Refractive Index Detector calibrated with polystyrene standards in chloroform as the eluent $\left(1 \mathrm{~mL} / \mathrm{min}, 25^{\circ} \mathrm{C}\right)$. The Differential Scanning Calorimetry (DSC) analyses were carried out on a DSC Q20 instrument calibrated according to standard procedures using a high purity Indium sample. For the analyses, samples $(5 \mathrm{mg})$ were placed into aluminium hermetic pans and heated from $-70^{\circ} \mathrm{C}$ to $160^{\circ} \mathrm{C}$, cooled to $160^{\circ} \mathrm{C}$ from $-70^{\circ} \mathrm{C}$, then heated from $-70{ }^{\circ} \mathrm{C}$ to $160^{\circ} \mathrm{C}$ at a rate of $10^{\circ} \mathrm{C} /$ min under nitrogen atmosphere. Thermogravimetry (TGA) analyses were performed on a Discovery TA Q 5500 instrument. Samples $(10 \mathrm{mg})$ were heated from 30 ${ }^{\circ} \mathrm{C}$ to $800{ }^{\circ} \mathrm{C}$ with a heating rate of $10^{\circ} \mathrm{C} / \mathrm{min}$ under nitrogen gas (balance: $10 \mathrm{~mL} / \mathrm{min}$, sample : $25 \mathrm{~mL} / \mathrm{min})$.

\section{Results and discussion}

\section{Monomers syntheses}

The diol-diamides 2a-g were synthesized by a two-step procedure starting from levulinic acid and linear aliphatic diamines of different chain length (Scheme 2). In the first step, levulinic acid was converted into a mixed anhydride using ethyl chloroformiate and was then allowed to react with the diamines to yield the diketones $1 \mathrm{a}-\mathrm{g}$. In the second step, the two keto groups were reduced with sodium borohydride, affording the targeted monomers 2a-g. The best overall yield of $73 \%$ was obtained from butane-1,4-diamine (compound 2c, Table 1). It is noteworthy that the preparation of $2 \mathrm{c}$ and $2 \mathrm{e}$ was scaled up to $20 \mathrm{~g}$. The structure of the compounds $2 \mathrm{a}$-g was confirmed by NMR spectroscopy $\left({ }^{1} \mathrm{H}\right.$ and $\left.{ }^{13} \mathrm{C}\right)$ and by high resolution mass spectrometry (Supporting Information section). The thermal properties, i.e. the melting, crystallization and degradation temperatures, were measured by DSC and TGA, respectively (Table 1).

An even-odd effect can be noticed with a lower melting temperatures and absence of crystallization for odd number of carbons in the central segment. Such even-odd behaviours are well known for amides containing monomers and polymers. ${ }^{23}$ The degradation temperatures define the polymerisation temperature window, which should not exceed 180 to $200^{\circ} \mathrm{C}$ depending on the size of the monomer. It can be seen that, the longer the monomer, the higher the thermal stability.

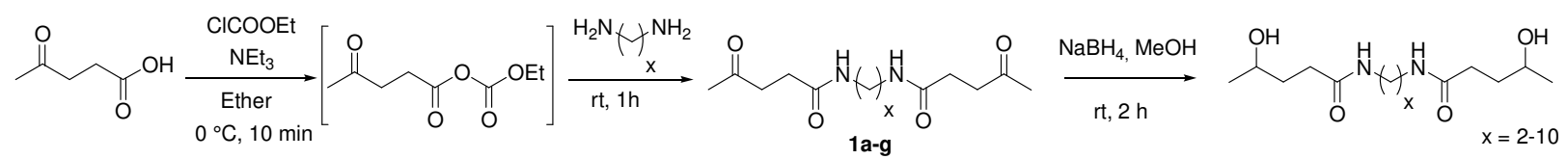

Scheme 2 Synthesis of diols-diamides (2a-g) from levulinic acid and diamines. 
Table 1 Yields and thermal properties of the monomers.

\begin{tabular}{|c|c|c|c|c|c|c|}
\hline Products & $\begin{array}{l}\text { Number of } \\
\text { carbons } x\end{array}$ & $\begin{array}{c}\text { Isolated Yields } \\
\text { (\%) } \\
\text { of } 1 \mathrm{a}-\mathrm{g}\end{array}$ & $\begin{array}{c}\text { Overall Yields } \\
(\%) \\
\text { of } 2 \mathrm{a}-\mathrm{g}\end{array}$ & $\begin{array}{c}T_{\text {melting }} \\
\left({ }^{\circ} \mathrm{C}\right)^{\mathrm{a}}\end{array}$ & $\begin{array}{c}T_{\text {crystallization }} \\
\left({ }^{\circ} \mathrm{C}\right)^{\mathrm{b}}\end{array}$ & $\begin{array}{c}T_{\text {degradation }} \\
\left({ }^{\circ} \mathrm{C}\right)^{\mathrm{C}}\end{array}$ \\
\hline $2 a$ & 2 & 75 & 51 & 116 & 64 & 199 \\
\hline $2 b$ & 3 & 57 & 41 & 79 & / & 183 \\
\hline $2 c$ & 4 & 98 & 73 & 98 & 77 & 212 \\
\hline $2 d$ & 5 & 82 & 57 & 95 & I & 223 \\
\hline $2 e$ & 6 & 93 & 71 & 110 & 78 & 211 \\
\hline $2 f$ & 8 & 87 & 62 & 108 & 95 & 239 \\
\hline $2 g$ & 10 & 78 & 33 & 116 & 99 & 225 \\
\hline
\end{tabular}


A first set of experiments was performed to assess the feasibility of the lipase-catalysed polymerisation and to identify the best reactions conditions. For this purpose the $C_{6}$ diol $2 \mathrm{e}$ and the $\mathrm{C}_{6}$ and $\mathrm{C}_{10}$ diacids and diesters were selected as monomers (Scheme 3 ). The different results are summarized in Table 2.

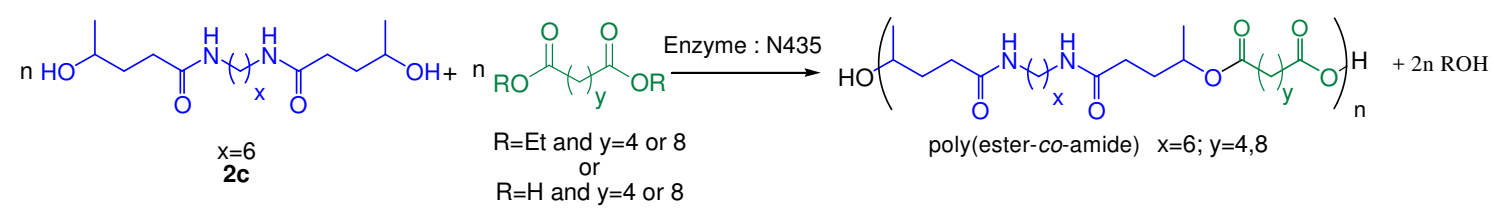

Scheme 3 Synthesis of poly(ester-co-amide)s by enzymatic polycondensation.

Table 2 Screening of reaction conditions with the $C_{6}$ diol-diamide 2 e to access to poly(esterco-amide)s. ${ }^{\text {a }}$

\begin{tabular}{|c|c|c|c|c|c|c|c|c|}
\hline $\begin{array}{c}\text { Entr } \\
y\end{array}$ & Comonomer & $\begin{array}{l}\text { Experimental } \\
\text { Conditions }\end{array}$ & $\begin{array}{c}\text { Concentra } \\
\text { tion } \\
\text { (mol/L) vs } \\
\text { diol }\end{array}$ & $\begin{array}{c}\text { Yield } \\
(\%)\end{array}$ & $\begin{array}{c}\underset{b}{M_{\mathrm{n} S E C}} \\
(\mathrm{~g} / \mathrm{mo} \\
\mathrm{l})\end{array}$ & $\underset{\mathrm{b}}{\oplus_{M}}$ & $\begin{array}{c}\text { Main } \\
\text { peak } \\
b, c \\
\text { wt (\%) }\end{array}$ & $\begin{array}{l}\text { Correct } \\
\text { ed } \\
\text { Yield } \\
(\%)^{d}\end{array}$ \\
\hline 1 & $\begin{array}{l}\text { diethyl } \\
\text { adipate }\end{array}$ & $\begin{array}{c}105^{\circ} \mathrm{C}, 6 \mathrm{~h} \\
(\mathrm{Patm}) \\
105^{\circ} \mathrm{C}, 60 \mathrm{~h} \\
(2 \mathrm{mbar})\end{array}$ & - & 82 & 500 & 1.7 & / & 82 \\
\hline 2 & $\begin{array}{l}\text { diethyl } \\
\text { adipate }\end{array}$ & $\begin{array}{c}81^{\circ} \mathrm{C}, 3 \text { days } \\
\left(\mathrm{P}_{\text {atm }}\right)\end{array}$ & 0.033 & 85 & 800 & 2.0 & 90 & 77 \\
\hline 3 & $\begin{array}{l}\text { diethyl } \\
\text { adipate }\end{array}$ & $\begin{array}{c}81^{\circ} \mathrm{C}, 7 \text { days } \\
\left(P_{\text {atm }}\right)\end{array}$ & 0.033 & 86 & 1,800 & 1.5 & 91 & 78 \\
\hline 4 & $\begin{array}{l}\text { diethyl } \\
\text { adipate }\end{array}$ & $\begin{array}{c}81^{\circ} \mathrm{C}, 10 \text { days } \\
\left(P_{a t m}\right)\end{array}$ & 0.033 & 86 & 2,200 & 1.6 & 92 & 80 \\
\hline 5 & $\begin{array}{c}\text { diethyl } \\
\text { sebacate }\end{array}$ & $\begin{array}{c}81^{\circ} \mathrm{C}, 7 \text { days } \\
\left(P_{\text {atm }}\right)\end{array}$ & 0.033 & 50 & 5,600 & 1.7 & 92 & 46 \\
\hline 6 & adipic acid & $\begin{array}{c}81^{\circ} \mathrm{C}, 7 \text { days } \\
\left(P_{\text {atm }}\right)\end{array}$ & 0.033 & 24 & 800 & 1.5 & 88 & 21 \\
\hline 7 & sebacid acid & $\begin{array}{c}81^{\circ} \mathrm{C}, 7 \text { days } \\
\left(P_{\text {atm }}\right)\end{array}$ & 0.033 & 26 & 2,600 & 1.8 & 93 & 24 \\
\hline 8 & $\begin{array}{l}\text { diethyl } \\
\text { adipate }\end{array}$ & $\begin{array}{c}81^{\circ} \mathrm{C}, 7 \text { days } \\
\left(P_{\text {atm }}\right)\end{array}$ & 0.025 & 80 & 1,900 & 1.6 & 77 & 62 \\
\hline 9 & $\begin{array}{l}\text { diethyl } \\
\text { adipate }\end{array}$ & $\begin{array}{c}81^{\circ} \mathrm{C}, 7 \text { days } \\
\left(P_{\text {atm }}\right)\end{array}$ & 0.050 & 72 & 1,700 & 1.5 & 92 & 67 \\
\hline 10 & $\begin{array}{l}\text { diethyl } \\
\text { adipate }\end{array}$ & $\begin{array}{c}81^{\circ} \mathrm{C}, 7 \text { days } \\
\left(P_{\text {atm }}\right)\end{array}$ & 0.10 & 90 & 3,300 & 1.5 & 92 & 83 \\
\hline
\end{tabular}

a diol-diamide/diester or diacid ( $2 \mathrm{mmol} / 2 \mathrm{mmol}$ ), enzyme $\mathrm{N} 435$ (10 wt\% weight), reaction in solution in Dean Stark apparatus (with molecular sieves $4 \AA$ replaced every $48 \mathrm{~h}$ for diester), solvent : cyclohexane [from $20 \mathrm{~mL}(0.1 \mathrm{~mol} / \mathrm{L}$ vs. diol) to $80 \mathrm{~mL}(0.025 \mathrm{~mol} / \mathrm{L}$ vs. diol)] ${ }^{b} \mathrm{SEC}$ in chloroform at $25^{\circ} \mathrm{C}$ (polystyrene standards), $M_{\mathrm{n}}$ and $\Xi_{M}$ for main peak ${ }^{c}$ main peak and secondary peaks distributions represent high $M_{\mathrm{n}}$ oligomers and small oligomers $\left(M_{\mathrm{n}}=400-600 \mathrm{~g} / \mathrm{mol}, \quad \bigoplus_{M}=1-1.2\right)$, respectively.

$\%$ by weight main peak = [area of main peak / (area of main peak + area of secondary peaks)] *100

${ }^{d}$ corrected yield $=$ yield $\mathrm{x}$ main peak $w t(\%) / 100$ 
Initial trials of enzymatic polycondensation were performed in bulk (solvent-free) under reduced pressure to remove ethanol and at a temperature over $100{ }^{\circ} \mathrm{C}$ to melt the diol monomer ( $\mathrm{T}_{\text {melting }}>95^{\circ} \mathrm{C}$ excepted for $2 \mathrm{~b}$, Table 1 ). A representative example is presented in entry 1 . Such conditions led to a low $M_{\mathrm{n}}$ oligomer $(800 \mathrm{~g} / \mathrm{mol})$ which may be ascribed to the high viscosity of the mixture hampering the removal of the ethanol by-product and reducing the stirring efficiency. It was not possible to decrease the viscosity with higher temperature without denaturing the enzyme.

The enzyme-catalysed polycondensation was then conducted in solution (entries 2-10). The choice of solvent is crucial for these reactions, as it can influence the activity, stability (denaturation) and selectivity of the lipase. As already described in the literature to allow the polycondensation of a secondary diol with diacids or diesters in cyclohexane, ${ }^{59}$ we decided to set the polymerisation at reflux with a Dean Stark trap (scheme of apparatus on Supporting Information S17). Furthermore, it was shown previously that hydrophobic solvents, like cyclohexane, can promote enzymatic activity. ${ }^{60}$

The reaction was conducted at different times $\left(3,7,10\right.$ days) in boiling cyclohexane $\left(81^{\circ} \mathrm{C}\right)$ using Novozyme 435 as catalyst and diethyl adipate as comonomer (entries 2-4). Seven days were required to improve the $M_{\mathrm{n}}$ with a yield of $78 \%$. The molecular weight distribution (entry 3, 7 days - Fig. 1) was composed of two populations. The main was related to a high $M_{\mathrm{n}}$ oligomer fraction $(1,800 \mathrm{~g} / \mathrm{mol})$. It was composed of small peaks below the main signal due to the presence of intermediate growing chains as the reaction was not complete after 7 days. The secondary population was related to a very small oligomer, probably a dimer $\left(M_{n}=400\right.$ $\mathrm{g} / \mathrm{mol}, 9 \%$ by weight). The weight ratio of each population was determined from the SEC area of the two zones. Unfortunately, attempts to remove the low $M_{n}$ oligomeric fraction from the product by precipitation in various solvents were unsuccessful. Decreasing the reaction time to 3 days reduced the number average molecular weight by a factor 2 . When the polymerisation was conducted for 10 days (entry 4 ) the $M_{n}$ was not substantially improved compared to 7 days reaction. The dispersities around 1.5-1.6 and the yield extent may be ascribed to a slow and uncompleted conversion kinetic of secondary diol via enzymatic catalyst in 7-10 days.

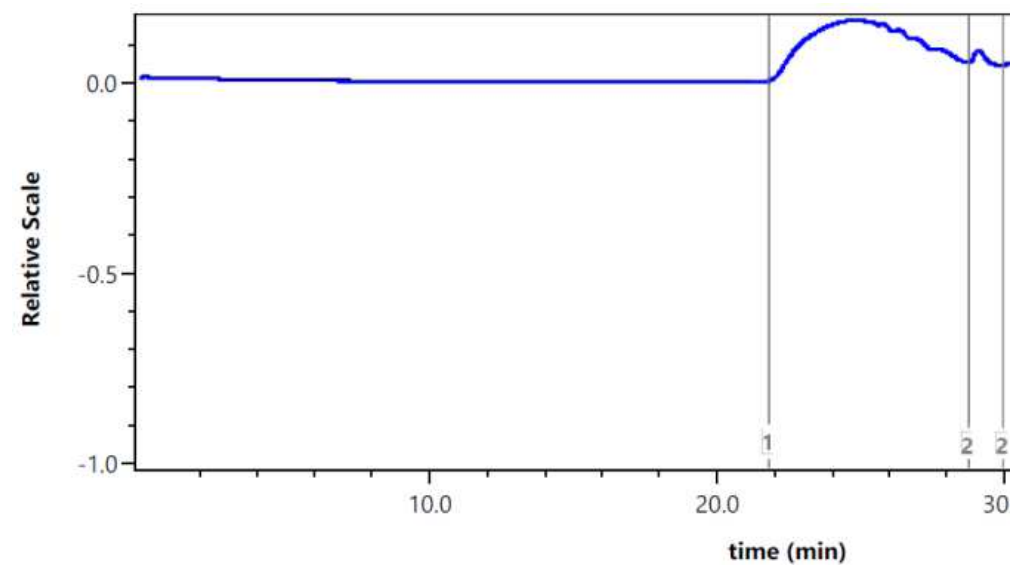

Fig. 1 SEC chromatogram of the polycondensation product (entry 3) obtained from dioldiamide $2 \mathrm{e}(\mathrm{x}=6)$ and diethyl adipate $\left(\mathrm{CHCl}_{3}, 25^{\circ} \mathrm{C}\right.$, standard PS). 
The ${ }^{1} \mathrm{H}$ NMR spectra resulting from the experiment depicted in entry 4 and from the monomers are presented in Fig. 1. The assignments were confirmed with a COSY experiment (Supporting Information S15). The formation of the polycondensation product was evidenced by the appearance of new signals on the spectrum, i.e. the $b$ signal at $4.8 \mathrm{ppm}$ and the $c$ signal at $1.7 \mathrm{ppm}$ attributed respectively to the protons in $\alpha$ and $\beta$ of the ester oxygen of the polymer backbone $\left[\mathrm{CH}_{2} \mathrm{CH}\left(\mathrm{CH}_{3}\right) \mathrm{OCO}\right]$. The integrations were in accordance with the structure of the polymer represented in Fig. $2 \mathrm{C}$. It could be noted that the signals characteristic of the terminal hydroxyl group (noted $\mathrm{m}$ at $4.4 \mathrm{ppm}$ ), the protons in $\alpha$ and $\beta$ position of this latter group (noted ' $b^{\prime}$ and $a^{\prime}$ at 3.6 and $1.0 \mathrm{ppm}$, respectively) and the ethyl adipate moiety $\left(\mathrm{CH}_{3} \mathrm{CH}_{2} \mathrm{OCO}\right.$ noted $\mathrm{k}$ at $4.1 \mathrm{ppm}$ ) were observed on the polymer spectrum (Fig. $2 \mathrm{C}$ ). They could be assigned to the chain-ends in view of the integral values $\left(\mathrm{I}_{\mathrm{a}+\mathrm{a}^{\prime}}=5.90\right.$ for $6 \mathrm{H}, \mathrm{I}_{\mathrm{b}+\mathrm{b}^{\prime}}=2.00$ for $\left.2 \mathrm{H}, \mathrm{I}_{\mathrm{m}}=\mathrm{I}_{\mathrm{b}^{\prime}}\right)$.

The structure was confirmed by MALDI-ToF analyses (Supporting Information S16). Different combinations of chain ends were observed: alcohol-alcohol, ester-ester and alcoholester associations and in negligible way alcohol-acid (non observable by NMR). The formation of cyclic structure was also observed in negligible quantity. 


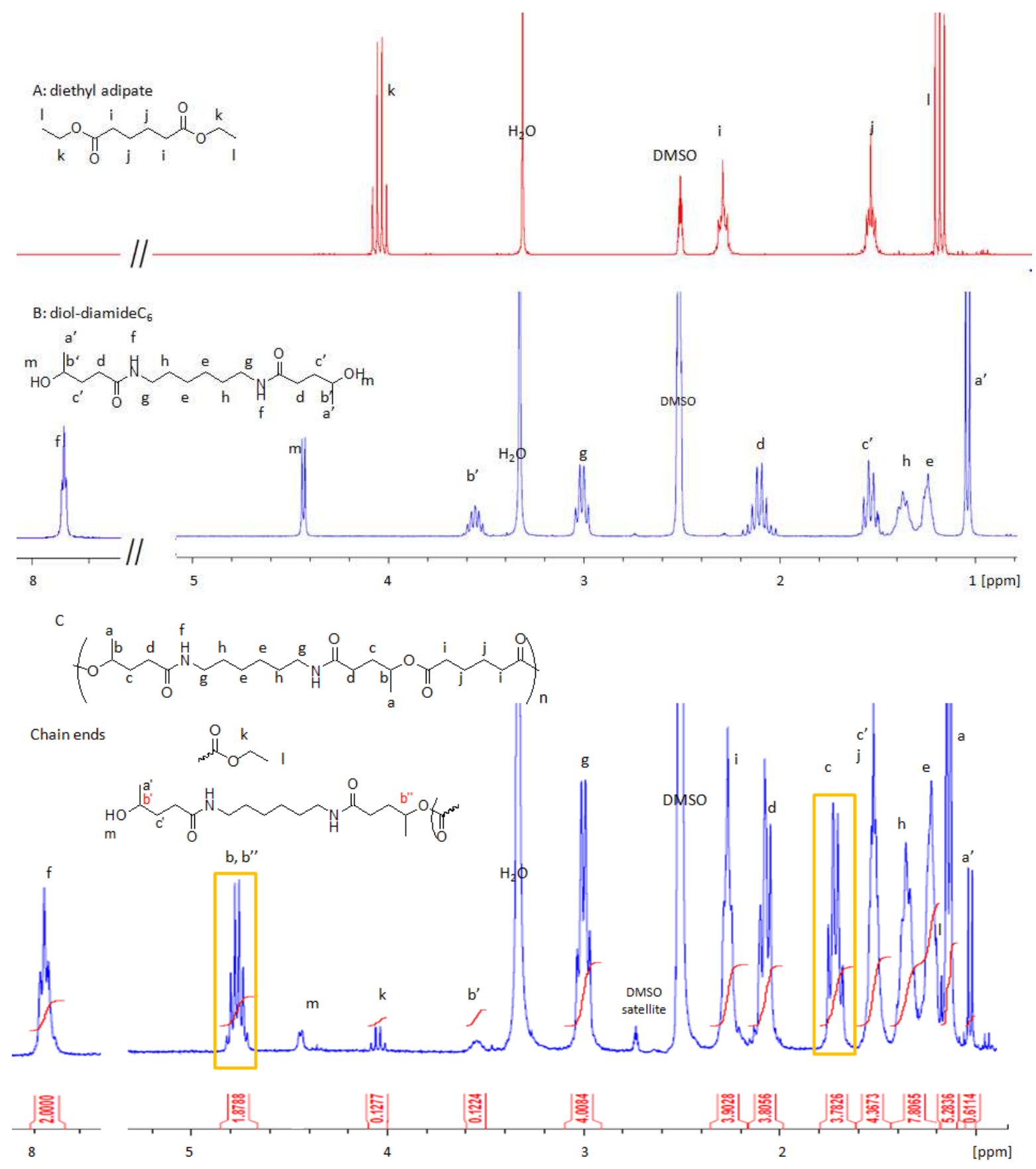

Fig. $2{ }^{1} \mathrm{H}$ NMR spectra of diethyl adipate $(A)$, the diol diamide monomer $(x=6, B)$ and polymer obtained after polycondensation (C, entry 4) (DMSO- $d_{6}, 300 \mathrm{MHz}$ )

The lipase N435 has generally better affinity with long chain monomers for polyesterification reactions. Indeed, it has been shown that increasing the diol and/or the diacid/diester length leads to higher molecular weight. ${ }^{59,61,62}$ Thus, the polycondensation reaction was conducted with diethyl sebacate $\left(C_{10}\right.$, entry 5$)$ instead of diethyl adipate $\left(C_{6}\right.$, entry 3). The longer diester chain led to a yield of $46 \%$ (vs. $78 \%$ for entry 3 ) but an improvement of $M_{n}$ was observed, 5,600 vs. $1,800 \mathrm{~g} / \mathrm{mol}$ for entries 5 and 3 respectively. The reactions from diacids as monomers instead of diesters were also explored (entries 6-7) but led to lower yields (21-24\%). As observed for diesters, increasing the length of the diacid from $C_{6}$ (adipic) to $C_{10}$ (sebacic) results in higher $M_{n}\left(2,600 \mathrm{~g} / \mathrm{mol}\right.$ for $C_{10} \mathrm{vs} .800 \mathrm{~g} / \mathrm{mol}$ for $\left.C_{6}\right)$. 
Additionally, the isolated product contains in this case a substantial amount of $\gamma$-valerolactone (26-28\% by weight, ${ }^{1} \mathrm{H}$ NMR, Supporting Information S18). It was reported on previous studies, that immobilized Candida antarctica lipase B can catalyse lactonization from hydroxy-ester toward $\gamma$-valerolactone via intramolecular cyclisation. A similar mechanism can be proposed in the case of diol-diamide (Scheme 4). ${ }^{63,64}$ This side-product was not detected when the reaction was conducted with the diesters. It may be explained by an enhanced electrophilicity of the amide in the presence of the diacid monomer. The lost of a $\gamma$-valerolactone unit was confirmed by MALDI-ToF analyses (Supporting Information S19). In view of these results, diesters were selected for the next steps of the study. Even if diethyl sebacate allowed achieving higher $M_{n}$, the diethyl adipate was selected as reference co-monomer as it gave the best yield/ $M_{\mathrm{n}}$ compromise.

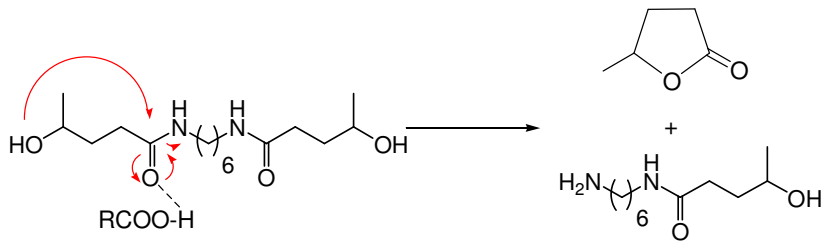

Scheme 4 Proposed side-reaction leading to the formation of $\gamma$-valerolactone in the presence of diacid comonomer.

The so formed poly(ester-co-amide)s were barely soluble in cyclohexane, thus affecting the polymerisation process. The influence of the concentration on the polymerisation was further studied with the aim to improve the polymer formation (entries 8-10 vs. 3 in Table 2). Generally, an increase of the number average molecular weight and yield could be noticed in a concentrated medium $[1,900 \mathrm{~g} / \mathrm{mol}$, yield $=62 \%$ for $0.025 \mathrm{~mol} / \mathrm{L}$ (entry 8) vs. 3,300 g/mol, yield $=83 \%$ for $0.1 \mathrm{~mol} / \mathrm{L}$ (entry 10)]. This result may be ascribed to a better interaction between reagents and enzyme (insoluble in cyclohexane) in concentrated medium. The byproduct of the reaction (ethanol) may also be more easily removed in a lower volume of solvent via Dean Stark process which could improve the conversion.

The enzymatic polycondensation of 2e with diesters as comonomers and Novozyme 435 as catalyst allows to achieve oligomers formation $(1,800-5,600 \mathrm{~g} / \mathrm{mol}$ in 7 days of reaction) with interesting yield in the case of diethyl adipate as co-monomer (62-83\%). The secondary alcohol was recognized by the lipase Novozyme 435, and the amide function did not interfere with the process.

The conditions described in entry 10 , the concentration $0.1 \mathrm{~mol} / \mathrm{L}$, offering the best yield and $M_{n}$, were selected for the polymerisation of the other diol-diamides (2a-g, $\left.\mathrm{x}=2-10\right)$ and are reported in Table 3 (experiments for a concentration of $0.033 \mathrm{~mol} / \mathrm{L}$ were also realised and are provided in Supporting Information Table S1). The enzyme-catalysed polycondensation led to oligo(ester-co-amide)s for all levulinic acid based diols-diamide monomers, with number-average molecular weight ranging from 1,500 to $7,200 \mathrm{~g} / \mathrm{mol}$. ${ }^{1} \mathrm{H}$ NMR and SEC chromatograms can be found in the Supporting Information section (S20-26 and S27 respectively). The polymerisation of diol with short chain length $(x=2,3,4,5)$ gave moderate $M_{\mathrm{n}}(1,800-2,100 \mathrm{~g} / \mathrm{mol}$, entries 11-14). The molecular weight can be improved $(3,300-7,200 \mathrm{~g} / \mathrm{mol})$ by increasing the chain length $(x=6,8,10)$ probably due to the better enzyme affinity for longer monomer chains.

The oligo(ester-co-amide)s were characterized by differential scanning calorimetry (DSC) (see Supporting Information S28-34 for the DSC curves). DSC curves showed a heat capacity jump between -23 and $0{ }^{\circ} \mathrm{C}$ (Table 3 ). The range of $\mathrm{T}_{\mathrm{g}}$ obtained was in accordance with previous study where similar poly(ester-co-amide)s had $\mathrm{T}_{\mathrm{g}}$ of $-11^{\circ} \mathrm{C} .^{23}$ It was also observed that the increase of the number of carbons in the monomer leads to a decrease of the glass transition temperature due to a increased mobility of the chains..$^{59,65}$ We observe similar trends, but the 
evolution is not monotonous probably due to the presence of low $M_{\mathrm{n}}$ oligomers that could influence slightly the $T_{g}$. For $x=8$ and $x=10$, the oligomers recrystallized during the second heating and a melting temperature was observed around $90-97{ }^{\circ} \mathrm{C}$ (Supporting Information S31-32). This observation showed that the high number of methylene in the repeating units tended to improve the ability of the oligomer to crystallize.

On the TGA curves (SI 35-41), two main degradation stages were observed and attributed to the ester and amide bonds respectively. Amide groups are known to be more stable than ester groups due to the partial double bond character of the C-N bond. ${ }^{66,67}$ The first degradation attributed to the ester parts was found to be around $180-205^{\circ} \mathrm{C}(3 \%$ of mass loss). The degradation temperature attributed to the amide part increased when the number of methylene increases from $2\left(355^{\circ} \mathrm{C}\right)$ to $10\left(378^{\circ} \mathrm{C}\right)$. 
Table 3 Influence of diol-diamide chain length on polycondensation reactions and thermal analyses. ${ }^{a}$

\begin{tabular}{|c|c|c|c|c|c|c|c|c|c|c|c|}
\hline $\begin{array}{c}\text { Entr } \\
y\end{array}$ & $\begin{array}{c}\text { Diol } \\
\text { diamide } \\
\text { Number } \\
\text { of } \\
\text { carbons } \\
x\end{array}$ & $\begin{array}{c}\text { Yield } \\
(\%)\end{array}$ & $\begin{array}{c}M_{\mathrm{n}} \\
\mathrm{SEC} \\
(\mathrm{g} / \mathrm{mo} \\
\mathrm{l})^{\mathrm{b}}\end{array}$ & $\underset{\mathrm{b}}{\oplus_{M}}$ & $\begin{array}{l}\text { Main } \\
\text { peak } \\
\text { wt (\%) }\end{array}$ & $\begin{array}{c}\text { Correct } \\
\text { ed } \\
\text { Yield } \\
(\%)^{d}\end{array}$ & $\begin{array}{l}\mathrm{Tg} \\
\left({ }^{\circ} \mathrm{C}\right. \\
)^{\mathrm{e}}\end{array}$ & $\begin{array}{c}\mathrm{T}_{\mathrm{c}} \\
\left({ }^{\circ} \mathrm{C}\right)^{\mathrm{e}}\end{array}$ & $\begin{array}{l}\mathrm{T}_{\mathrm{m}} \\
\left({ }^{\circ} \mathrm{C}\right. \\
)^{\mathrm{e}}\end{array}$ & $\begin{array}{l}T_{\text {de }} \\
\text { g } 1 \\
\left(^{\circ} \mathrm{C}\right. \\
)^{f}\end{array}$ & $\begin{array}{l}T_{\text {deg }} 2 \\
\left({ }^{\circ} \mathrm{C}\right)^{\mathrm{g}}\end{array}$ \\
\hline 11 & 2 & 81 & 1,500 & 1.4 & 88 & 71 & -5 & I & / & $\begin{array}{c}18 \\
7\end{array}$ & 355 \\
\hline 12 & 3 & 92 & 2,300 & 1.4 & 91 & 84 & -9 & / & / & $\begin{array}{c}19 \\
8\end{array}$ & 360 \\
\hline 13 & 4 & 65 & 2,300 & 1.6 & 86 & 56 & 0 & / & / & $\begin{array}{c}20 \\
1\end{array}$ & 365 \\
\hline 14 & 5 & 88 & 1,800 & 1.5 & 91 & 80 & -10 & / & I & $\begin{array}{c}20 \\
2\end{array}$ & 373 \\
\hline 10 & 6 & 90 & 3,300 & 1.5 & 92 & 83 & -12 & / & / & $\begin{array}{c}20 \\
5\end{array}$ & 375 \\
\hline 15 & 8 & 85 & 4,200 & 1.8 & 91 & 78 & -23 & 72 & 90 & $\begin{array}{c}18 \\
0\end{array}$ & 376 \\
\hline 16 & 10 & 71 & 7,200 & 1.6 & 91 & 65 & -14 & $\begin{array}{c}28 \text { and } \\
49\end{array}$ & 97 & $\begin{array}{c}20 \\
3\end{array}$ & 378 \\
\hline
\end{tabular}

a reaction at $81^{\circ} \mathrm{C}$ for 7 days in $20 \mathrm{~mL}$ or $60 \mathrm{~mL}$ of cyclohexane $(0.10 \mathrm{~mol} / \mathrm{L}$ vs. diol), dioldiamide/diester ( $2 \mathrm{mmol} / 2 \mathrm{mmol}$ ), Novozyme 435 (10\% weight vs. monomers), Dean Stark apparatus with molecular sieves (replaced every $48 \mathrm{~h}$ )

${ }^{b} \mathrm{SEC}$ in chloroform at $25^{\circ} \mathrm{C}$ (polystyrene standards), $M_{\mathrm{n}}$ and $\Xi_{M}$ for main peak

${ }^{c}$ main peak and secondary peaks distributions represent high $M_{\mathrm{n}}$ oligomers and small oligomers $\left(M_{\mathrm{n}}=300-800 \mathrm{~g} / \mathrm{mol}, \quad \bigoplus_{M}=1-1.3\right)$, respectively.

$\%$ by weight main peak = [area of main peak / (area of main peak + area of secondary peaks)] *100

${ }^{\mathrm{d}}$ corrected yield $=$ yield $\mathrm{x}$ main peak wt(\%) / 100

e $T_{g}, T_{c}$ (crystallization) and $T_{m}$ (melting) determined by DSC on the second heating step.

${ }^{f}$ TGA temperatures at which $3 \%$ of the mass was lost

$g$ TGA temperatures for start of second degradation (inflection point of weight $=f(T)$ )

\section{CONCLUSIONS}

We have synthesized herein a new family of poly(ester-co-amide) polymers. A library of biobased aliphatic diol-diamide monomers with different chain lengths was synthesized from levulinic acid and linear aliphatic diamines through an $\mathrm{N}$-Acylation/reduction procedure. These secondary diol based monomers were polymerised under mild conditions via enzymatic catalysis to access oligo(ester-co-amide)s. The polycondensation in bulk at $\mathrm{T}>100{ }^{\circ} \mathrm{C}$ led to low $M_{\mathrm{n}}$ oligomers $(800 \mathrm{~g} / \mathrm{mol})$, while the reactions conducted in refluxing cyclohexane with a Dean Stark apparatus led to higher $M_{\mathrm{n}}$ product. The nature and length of the comonomer (diacid/diester, $\mathrm{C}_{6} / \mathrm{C}_{10}$ ) were found to have a significant effect on the polymerisation. When the polymerisations were performed with diacids, $\gamma$-valerolactone was formed as a side product. The $M_{\mathrm{n}}$ increases when the reaction was conducted with both $\mathrm{C}_{10}$ diacid and diester instead of $\mathrm{C}_{6}$ analogs. But concerning diester, the yield was divided by a factor close to 2 with $\mathrm{C}_{10}$ compared to $\mathrm{C}_{6}$. The polycondensation of the different diol-diamide monomers with diethyl adipate catalysed with Novozyme 435 allowed to prepare oligo(ester-co-amide)s with number average molecular weights in the range 1,500 - 7,200 g/mol, dispersities between 1.4 
and 1.8 and yield between $56-84 \%$. The aliphatic secondary diol was recognized by the lipase Novozyme 435 whichever the number of methylene when in fact lipases are usually known to be poorly reactive with secondary hydroxyl groups. This is, to our knowledge, the first example of a step-growth synthesis of poly(ester-co-amide) polymers from a secondary diol via biocatalysis. This biocatalysed synthesis of levulinic acid based poly(ester-co-amide) is complementary to our previous work on metal catalysed polycondensations allowing the access to poly(amine-co-ester)s ${ }^{14}$ and polyesters bearing a pendant lactam group ${ }^{15}$ from levulinic acid based monomers obtained via reductive amination. The molecular weight could be improved $(3,300-7,200 \mathrm{~g} / \mathrm{mol})$ by increasing the chain length of the diol $(x=6,8,10)$. All polycondensation products exhibited a glass transition temperature between -23 and $-0{ }^{\circ} \mathrm{C}$. The stability of the amide part was slightly higher when the number of methylene increases from $2\left(355^{\circ} \mathrm{C}\right)$ to $10\left(378^{\circ} \mathrm{C}\right)$. Such polymers could serve as drug delivery systems or for tissue engineering applications, as an alternative to aminoacid based poly(ester-co-amide).

\section{Conflicts of interest}

There are no conflicts to declare.

\section{Acknowledgements}

This research was financially supported by the FWV ALPO Interreg Grant. The authors thank the European Regional Development Fund (ERDF), the University of Lille and the University of Mons. The Chevreul Institute (FR 2638), the Ministère de I'Enseignement Supérieur, de la Recherche et de I'Innovation, and Région Hauts de France are also acknowledged for supporting and funding partially this work. The MS lab (PG) is grateful to the "Fonds de la Recherche Scientifique" (FRS-FNRS) for financial support for the acquisition of the Waters Synapt G2-Si mass spectrometer (GE U G007.15). JMR is a FRS-FNRS research fellow. The authors thank Novozymes, which provided the Novozyme 435. Aurélie Malfait, Fanny Bonnet, Johan Sarazin and Benjamin Dewailly are gratefully acknowledged for SEC and thermal measurements.

\section{Statement of contributions}

Conception and design of the study, JM, YB, SP, TB, LP, AFH and PZ, Monomers synthesis YB and $\mathrm{SP}$, Monomer analysis $\mathrm{YB}, \mathrm{SP}$ and $\mathrm{PG}$, Polymer synthesis via enzymatic catalysis $\mathrm{JM}$ and TC, Polymer analysis JM, JDW, VG, JFT, FC and JMR, writing JM, YB and PZ, reading of the manuscript and critical discussion, all authors.

\section{Notes and references}

1 I. Delidovich, P. J. C. Hausoul, L. Deng, R. Pfützenreuter, M. Rose and R. Palkovits, Chem. Rev., 2016, 116, 1540.

2 L. T.' Mika, E. Cséfalvay and Á. Németh, Chem. Rev., 2017, 118, 505.

3 P. F. H. Harmsen, M. M. Hackmann and H. L. Bos, Biofuels Bioprod. Biorefin., 2014, 8, 306.

4 T. Werpy and G. Petersen, Top Value Added Chemicals from Biomass: Volume I-Results of Screening for Potential Candidates from Sugars and Synthesis Gas, 2004.

5 C. Antonetti, D. Licursi, S. Fulignati, G. Valentini and A. M. Raspolli Galletti, Catalysts, 2016, 6, 196 .

6 B. Girisuta, L. P. B. M. Janssen and H. J. Heeres, Green Chem., 2006, 8, 701.

7 M. A. Mellmer, J-M. R. Gallo, D. M. Alonso and J. A. Dumesic, ACS Catal., 2015, 5, 3354.

8 F. D. Pileidis and M. Titirici, ChemSusChem, 2016, 9, 562. 
9 J-F. L. Silva, R. Grekin, A. P. Mariano and R. M. Filho, Energy Technol., 2018, 6, 613.

10L. Yan, Q. Yao and Y. Fu, Green Chem., 2017, 19, 5527.

11 K. Huang, S. Ma, S. Wang, Q. Li, Z. Wu, J. Liu, R. Liu and J. Zhu, Green Chem., 2019, 21,4964.

12 W. Xuan, M. Hakkarainen and K. Odelius, ACS Sustainable Chem. Eng., 2019, 7, 12552.

13 A. Sinisi, M. D. Esposti, M. Toselli, D. Morselli and P. Fabbri, ACS Sustainable Chem. Eng., 2019, 7, 13920.

14 Y. Bernhard, L. Pagies, S. Pellegrini, T. Bousquet, A. Favrelle, L. Pelinski, P. Gerbaux and P. Zinck, Green Chem., 2019, 21, 123.

15 Y. Bernhard, S. Pellegrini T. Rnısnuet A Favrelle I Pelinski, F. Cazaux, V. Gaucher, P. Gerbaux and P. Zinck, ChemSusChem, 2019, 12, 3370.

16 M. Hartweg and C. R. Becer, Green Chem., 2016, 18, 3272.

17 A. S. Amarasekara, U. Ha and N. C. Okorie, J. Polym. Sci. Part Polym. Chem., 2018, 56, 955.

18 R. D. Ashby, D. K. Y. Solaiman, G. D. Strahan, C. Zhu, R. C. Tappel and C. T. Nomura, Bioresour. Technol., 2012, 118, 272.

19J. A. Moore and T. Tannahill, High Perform. Polvm 2001 135305

20 M. Chalid, H. J. Heeres and A. A. Broekhuis, Polym. Plast. Technol. Eng., 2015, 54, 234.

21 M. Chalid, H. J. Heeres and A. A. Broekhuis, Adv. Mater. Res., 2013, 789, 274.

22 M. Chalid, Adv. Mater. Res., 2011, 277, 112.

23 H. R. Stapert, P. J. Dijkstra and J. Feijen, Macromol. Symp., 1998, 130, 91.

24 K. M. Zia, A. Noreen, M. Zuber, S. Tabasum and M. Mujahid, Int. J.'Biol. Macromol., 2016, 82, 1028.

25 Y. Lee, E. E. Kwon and J. Lee, Rev. Environ. Sci. Biotechnol., 2019, 18, 317.

26Y. Lee, K. A. Lin, E. E. Kwon and J. Lee, J. Clean. Prod., 2019, 227, 624.

$27 Y$. Jiang and K. Loos, Pnlvmers Jn16 $82 \Delta 3$

28 K. Guo and C. C. Chu, J. Biomed. Mater. Res. B, 2009, 89, 491.

29 K. Guo and C. C. Chu, J Biomater Sci Polym, 2007, 18, 489.

30 P. Karimi, A. S. Rizkalla and K. Mequanint, Materials, 2010, 3, 2346.

$31 \mathrm{H}$. Dodiuk-Kenig, K. Lizenboim, I. Eppelbaum, B. Zalsman and S. Kenig, J. Adhes. Sci. Technol., 2004, 18, 1723.

32 S. Bera, Z. Jedliński, Polymer, $199232 \Delta 321$

33 M. Kluge, D. N. Bikiaris, T. Robert, Eur. Polym. J., 2019, 120, 109195.

$34 \mathrm{M}$ Klıge H Rennhofer, H. C. Lichtenegger, F. W. Liebner, T. Robert, Eur. Polym. J., 2020 , in press doi: https://doi.org/10.1016/j.eurpolymj.2020.109622

35 P. A. M. Lips, R. Broos, M. J. M. Van Heeringen, P. J. Dijkstra, J. Feijen, Polymer, 2005, 46, 7823.

36 A. Rodriguez-Galan, L. Franco and J. Puiggali, Polymers, 2011, 3, 65.

37 A. C. Fonseca, A. C. Serra, J. F.J. Coelho, M. H. Gil and'P. N. Simões, Polym. Int., 2013, 62, 736.

38 J. Helder, F. E. Kohn, S. Sato, J. W. Van den Berg and J. Feijen, Makromol. Chem. Rapid Commun., 1985, 6, 9 .

39 Y. Feng, J. Knüfermann, D. Klee and H. Höcker, Macromol. Rapid Commun., 1999, 20, 88.

40X. Wang and N. Hadjichristidis, ACS Macro Lett., 2020, 9, 464.

41 R. Katsarava, Macromol. Symp., 2003, 199, 419.

42 R. Katsarava, V. Beridze, N. Arabuli, D. Kharadze, C. C. Chu and C. Y. Won, J. Polym. Sci. A Polym. Chem., 1999, 37, 391.

43 L. Asín, E. Armelin, J. Montané, A. Rodríguez-Galán and J. Puiggalí, J. Polym. Sci. A : Polym. Chem., 2001, 39, 4283.

44 A. Douka, S. Vouyiouka, L. Papaspyridi and C. D. Papaspyrides, Progress Polym. Sci., 2018, 79, 1.

$45 \mathrm{~L}$. Ragupathy, U. Ziener, R. Dyllick-Brenzinger, B. Von Vacano and K. Landfester, J. Mol. Catal. B Enzym., 2012, 76, 94.

46D. Maniar, F. Silvianti, V. M. Ospina, A. J. J. Woortman, J. Van Dijken, K. Loos, Polymer, 2020, 205, 122662.

47 B. Sharma, A. Azim, H. Azim, R. A. Gross, E. Zini, M. L. Focarete and M. Scandola, Macromolecules, 2007, 40, 7919.

48 A. Mahapatro, B. Kalra, A. Kumar and R. Gross, Biomacromolecules, 2003, 4, 544.

49T. Debuissy, E. Pollet and L. Avérous, Eur. Polym. J., 2017, 97, 328.

50 A. Mahapatro, B. Kumar, B. Kalra and R. Gross, Macromolecules, 2004, 37, 35.

51 D. Maniar, Y. Jiang, A. J. J. Woortman, J. Van Dijken and K. Loos, ChemSusChem, 2019, $12,990$.

52 S. Baraldi, G. Fantin, G. Di Carmine, D. Ragno, A. Brandolese, A. Massi, O. Bortolini, N. Marchetti and P. P. 'Giovannini, RSC Adv., 2019, 9, 29044.

53 E. Stavila, R. Z. Arsyi, D. M. Petrovic and K. Loos, Eur. Polym. J., 2013, 49, 834.

54 Y. Jiang, D. Maniar, A. J. J. Woortman and K. Loos, RSC Adv., 2016, 6, 67941.

$55 \mathrm{M}$. Finnveden, P.' Hendil-Forssell, M. Claudino, M. Johansson and M. Martinelle, Polymers, 2019, 11, 1730. 
56 A. Kumar, A. S. Kulshrestha, W. Gao and R. A. Gross, Macromolecules, 2003, 36, 8219. 57 K. R. Yoon, S. Hong, B. Kong and I. S. Choi., Synth. Commun., 2012, 42, 3504.

58I. Hilker, G. Rabani, G. K. M. Verzijl, A. R. A. Palmans and A. Heise, Angew. Chem. Int. Ed., 2006, 45, 2130.

59D. Juais, A. F. Naves, C. Li, R. A. Gross and L. H. Catalani, Macromolecules, 2010, 43, 10315.

$60 \mathrm{E}$. Wehtje, J. Kaur, P. Adlercreutz, S. Chand and B. Mattiasson, Enzyme Microb. Technol., 1997, 21, 502.

61 Y I inkn.'7. Wang and I Sennälä Fnzvme Mirroh. Terhnol 199517506

62 M. Hunsen, A. Azim, H. Mang, S. R. Wallner, A. Ronkvist, W. Xie and R. A. Gross, Macromolecules, 2007, 40, 148.

$63 \mathrm{~K}$. Götz, A. Liese, M. Ánsorge-Schumacher and L. Hilterhaus, Appl. Microbiol. Biotechnol., 2013, 97, 3865.

64 G. C. Clososki, C. E. Costa, L. J. Missio, Q. B. Cass and J. V. Comasseto, Synth. Commun., 2004, 34, 817.

65 C. Girard, M. Ġupta, A. Lallam, D. V. Anokhin, P. V. Bovsunovskaya, A. F. Akhyamova, A. P. Melnikov, A. A. Piryazev, A. I. Rodygin, A. A. Rychkov, K. N. Grafskaya, E. D. Shabratova, X. Żhu, M. Möller, D. A. Ivanov, Polym. Bull., 2019, 76, 495.

66 Y. P. Ge, D. Yuan, Z. L. Luo and B. B. Wang, Express Polym. Lett., 2014, 8, 50.

67Z. Qian, S. Li, Y. He, C. Li and X. Liu, Polym. Degrad. Stab., 2003, 81, 279. 